\title{
Publisher Correction: The mutational impact of culturing human pluripotent and adult stem cells
}

\author{
Ewart Kuijk (D), Myrthe Jager (D), Bastiaan van der Roest (D), Mauro D. Locati, Arne Van Hoeck (D, \\ Jerome Korzelius (1), Roel Janssen (1), Nicolle Besselink (1), Sander Boymans (1), Ruben van Boxtel (D) \& \\ Edwin Cuppen (1)
}

Correction to: Nature Communications https://doi.org/10.1038/s41467-020-16323-4, published online 19 May 2020.

The original version of this Article contained errors in the Results and Discussion sections, where 8 base substitution types incorrectly read " $\mathrm{C}>\mathrm{T}$." The correct version states " $\mathrm{C}>\mathrm{A}$ " in place of " $\mathrm{C}>\mathrm{T}$."

The Results also incorrectly represented 3 base substitution types with the symbol "-". The correct version uses ">" instead of "-".

This has been corrected in both the PDF and HTML versions of the Article.

Published online: 04 August 2020

\begin{abstract}
(c) (i) Open Access This article is licensed under a Creative Commons Attribution 4.0 International License, which permits use, sharing, adaptation, distribution and reproduction in any medium or format, as long as you give appropriate credit to the original author(s) and the source, provide a link to the Creative Commons license, and indicate if changes were made. The images or other third party material in this article are included in the article's Creative Commons license, unless indicated otherwise in a credit line to the material. If material is not included in the article's Creative Commons license and your intended use is not permitted by statutory regulation or exceeds the permitted use, you will need to obtain permission directly from the copyright holder. To view a copy of this license, visit http://creativecommons.org/licenses/by/4.0/.
\end{abstract}

(C) The Author(s) 2020 